\title{
A fast screening method for tricyclic antidepressants and their urinary metabolites by FAB-tandem mass spectrometry
}

\author{
M. Schäfer and H. Budzikiewicz \\ Institut für Organische Chemie der Universität zu Köln, Greinstrasse 4, D-50939 Köln, Germany \\ H. Brzezinka \\ Institut für Rechtsmedizin der Unversität Bonn, Stiftsplatz 12, D-53111 Bonn, Germany \\ M. Schifferdecker \\ Klinik und Poliklinik für Psychiatrie und Psychotherapie der Universität zu Köln, \\ Joseph-Stelzmann-Strasse 9, D-50924 Köln, Germany
}

\begin{abstract}
A screening method for tricyclic antidepressants (TCA) and their urinary metabolites by FAB tandem mass spectrometry (FAB MS/MS) is presented. The collision induced dissociation (CID) behavior of pure dibenzocycloheptadienes (amitriptyline 1, nortriptyline 2), dibenzoxepines (doxepine 3, dosulepine 4), dibenzazepines (imipramine 5, desipramine $\mathbf{6}$, trimipramine 7) and the iminostilbene derivative opipramol $\mathbf{8}$ is described and used for the specific determination of these tricyclics by MS/MS.

For the screening procedure a methanolic extract of the urine sample is passed through a XAD-2 column and the eluate is examined without further purification after evaporation of the solvent. Identification of the TCA is achieved by constant neutral loss (CNL) scans for $173 \mathrm{u}, 195 \mathrm{u}$ and $193 \mathrm{u}$ and subsequent daughter ion spectra of the molecular ions $[\mathrm{M}+\mathrm{H}]^{+}$. Glucuronide conjugate metabolites of the tricyclic antidepressants $\mathbf{1}, \mathbf{2}, \mathbf{3}, \mathbf{6}, \mathbf{8}$ could be identified by CNL-scans (176 u) and the assignments were confirmed by daughter ion mass spectra. A urine sample of a fatal $\mathbf{1}, \mathbf{2}, \mathbf{8}$ overdose and samples of three patients under therapeutic dosage with 1, $\mathbf{3}$ or $\mathbf{6}$ are presented as examples for application.
\end{abstract}

\section{Introduction}

Tricyclic antidepressants (TCA) have been used for treatment of depression for over 25 years [1]. Due to their widespread prescription to persons with suicidal tendencies frequent intoxications have been observed [2]. Especially in the case of overdoses a rapid screening for TCA in human urine is necessary [3]. Another potential application for urine TCA screening is the testing of forensic drug abuse.

Immunoassay screening is recommended because of its speed and simplicity, but as many HPLC methods are, it is not sufficiently reliable due to possible interferences of similar compounds [3]. Screening for TCAs in the urine by gas chromatography/mass spectrometry (GC/MS) requires adequate sample preparation: extraction or chromatographic isolation, hydrolysis of conjugated metabolites (e.g., glucuronide conjugates) and derivatization of polar metabolites. Identification may be achieved 
in addition to mass spectrometry by UV or NMR [4-6]. This labor and time consuming procedure is appropriate for metabolite structure determination, but it is too costly for screening.

In tandem mass spectrometry (MS/MS) the mass spectrometer serves both as separation device and as a tool for structure elucidation [5]. Using the ionization technique of fast atom bombardment (FAB) the drugs and their polar metabolites present in urine or other biological matrices (e.g., serum) can be identified directly and characterized without extensive sample work-up [7,8].

The elimination of TCAs from the body takes place almost exclusively by biotransformation into polar metabolites which are subsequently excreted with the urine or feces. Common pathways of metabolism are $\mathrm{N}$-demethylation, $\mathrm{N}$-oxidation, aliphatic and/or aromatic hydroxylations, $\mathrm{N}$ glucuronidation of tertiary amines and O-glucuronidation of hydroxylated metabolites. In this context it is important to notice that individual variations in metabolism lead to large differences in the amounts of the various metabolites formed [9]. It was, therefore, of importance to find a method which allows detection independent from metabolic transformations. As the main metabolic transformations leave the tricyclic skeleton of the TCAs intact, not only the detection of the unchanged drug, but also the selective identification of hydroxylated metabolites and of glucuronide conjugates is possible by adequate MS techniques: selective identification of TCAs is possible because corresponding structural features lead to analogous fragmentation characteristics under collision induced dissociation (CID) conditions.

\section{Experimental}

\subsection{Chemicals}

All tricyclic antidepressants were analyzed as hydrochlorides and were provided by the Institut für Rechtsmedizin; Bonn University. $\mathrm{CH}_{3} \mathrm{OH}$ and $\mathrm{H}_{2} \mathrm{O}$ was distilled prior to use. FAB matrices: anhydrous glycerol was purchased from FLUKA (Buchs, Switzerland); 1-thioglycerol from SIGMA (St Louis, MO, USA).

\subsection{Urine samples}

The urine samples 1-3 came from the Klinik und Poliklinik für Psychiatrie und Psychotherapie; Cologne University, and were taken in the morning from patients under daily medication with tricyclic antidepressants. The urine sample 4 (TCA-overdose) was provided by Institut für Rechtsmedizin; Bonn University. All urine samples were stored at $-25^{\circ} \mathrm{C}$ until analyzed. For determination of the recovery limit urine was spiked with authentic samples and worked up as described below. For each compound $1 \mu \mathrm{g} / \mathrm{ml}$ urine (S/N-ratio $5: 1$ ) could be detected.

\subsection{Analysis of the urine samples}

A $2 \mathrm{ml}$ portion of the urine sample combined with $2 \mathrm{ml}$ of $0.01 \mathrm{M}$ borate-buffer $(\mathrm{pH}=9.22$, MERCK, Darmstadt, Germany) was passed over a XAD-2 column $(15 \times 150 \mathrm{~mm})$. The column was

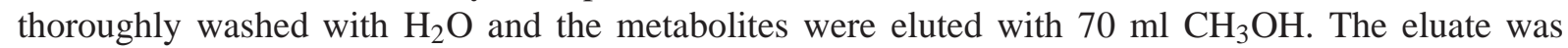
evaporated i.v. to dryness and the resultant residue was analyzed by mass spectrometry.

All positive ion FAB-experiments were carried out with a FINNIGAN MAT (Bremen, Germany) HSQ 30 instrument with BEqQ geometry equipped with a FAB-gun from ION TECH LTD (Teddington, 
Table 1

\begin{tabular}{|c|c|c|c|c|c|}
\hline Compound & $\begin{array}{l}\text { Parent ion } \\
{[\mathrm{M}+\mathrm{H}]^{+}} \\
\mathrm{m} / \mathrm{z}\end{array}$ & $\begin{array}{l}\text { Daughter ions } \\
\mathrm{m} / \mathrm{z}\end{array}$ & $\begin{array}{c}\text { Rel. } \\
\text { Abund. } \\
\%\end{array}$ & $\begin{array}{l}\text { CNL- } \\
173 \mathrm{u}\end{array}$ & $\begin{array}{l}\text { Rel. } \\
\text { Abund. } \\
\%\end{array}$ \\
\hline Amitriptyline 1 & 278 & $\begin{array}{ll}233 & {\left[\mathrm{MH}-\mathrm{NH}\left(\mathrm{CH}_{3}\right)_{2}\right]^{+}} \\
117 & {\left[\mathrm{C}_{9} \mathrm{H}_{9}\right]^{+}} \\
105 & {\left[\mathrm{C}_{8} \mathrm{H}_{9}\right]^{+}} \\
91 & {\left[\mathrm{C}_{7} \mathrm{H}_{7}\right]^{+}} \\
84 & {\left[\mathrm{CH}_{2}=\mathrm{CH}-\mathrm{CH}=\mathrm{N}\left(\mathrm{CH}_{3}\right)_{2}\right]^{+}} \\
58 & {\left[\mathrm{CH}_{2}=\mathrm{N}\left(\mathrm{CH}_{3}\right)_{2}\right]^{+}} \\
191, & 155,129,55\end{array}$ & $\begin{array}{c}17 \\
57.5 \\
74.8 \\
100 \\
60.9 \\
56.2 \\
\leqslant 8\end{array}$ & 278 & 100 \\
\hline Nortriptyline 2 & 264 & $\begin{array}{ll}233 & {\left[\mathrm{MH}-\mathrm{NH}_{2} \mathrm{CH}_{3}\right]^{+}} \\
117 & {\left[\mathrm{C}_{9} \mathrm{H}_{9}\right]^{+}} \\
105 & {\left[\mathrm{C}_{8} \mathrm{H}_{9}\right]^{+}} \\
91 & {\left[\mathrm{C}_{7} \mathrm{H}_{7}\right]^{+}} \\
70 & {\left[\mathrm{CH}_{2}=\mathrm{CH}-\mathrm{CH}=\mathrm{NH}_{2}\left(\mathrm{CH}_{3}\right)\right]^{+}} \\
191, & 129,155\end{array}$ & $\begin{array}{c}48.1 \\
87.6 \\
100 \\
96.5 \\
37.3 \\
\leqslant 7\end{array}$ & 264 & 100 \\
\hline Doxepine 3 & 280 & $\begin{array}{ll}235 & {\left[\mathrm{MH}-\mathrm{NH}\left(\mathrm{CH}_{3}\right)_{2}\right]^{+}} \\
117 & {\left[\mathrm{C}_{9} \mathrm{H}_{9}\right]^{+}} \\
107 & {\left[\mathrm{C}_{7} \mathrm{H}_{7} \mathrm{O}\right]^{+}} \\
91 & {\left[\mathrm{C}_{7} \mathrm{H}_{7}\right]^{+}} \\
84 & {\left[\mathrm{CH}_{2}=\mathrm{CH}-\mathrm{CH}=\mathrm{N}\left(\mathrm{CH}_{3}\right)_{2}\right]^{+}} \\
58 & {\left[\mathrm{CH}_{2}=\mathrm{N}\left(\mathrm{CH}_{3}\right)_{2}\right]^{+}} \\
241, & 207,195,154,128\end{array}$ & $\begin{array}{l}11.2 \\
15.2 \\
100 \\
12.9 \\
24.5 \\
23.8 \\
\leqslant 8\end{array}$ & 280 & 100 \\
\hline Dosulepine 4 & 296 & $\begin{array}{ll}251 & {\left[\mathrm{MH}-\mathrm{NH}\left(\mathrm{CH}_{3}\right)_{2}\right]^{+}} \\
123 & {\left[\mathrm{C}_{7} \mathrm{H}_{7} \mathrm{~S}\right]^{+}} \\
117 & {\left[\mathrm{C}_{9} \mathrm{H}_{9}\right]^{+}} \\
91 & {\left[\mathrm{C}_{7} \mathrm{H}_{7}\right]^{+}} \\
58 & {\left[\mathrm{CH}_{2}=\mathrm{N}\left(\mathrm{CH}_{3}\right)_{2}\right]^{+}} \\
218, & 209,191,173\end{array}$ & $\begin{array}{l}26.3 \\
28.9 \\
65.1 \\
27.0 \\
100 \\
\leqslant 15\end{array}$ & 296 & 100 \\
\hline
\end{tabular}

UK) (FAB-gas: Xe; FAB-potential: $8 \mathrm{kV}$; ion source: $25^{\circ} \mathrm{C}$; matrix: glycerol or 1-thioglycerol). $\mathrm{CID}$-experiments were performed in the collision quadrupole operating in the Rf-only mode (collision energy: $30 \mathrm{eV}$; collision gas: Ar; collision gas pressure: $0.45 \mathrm{mPa}$; attenuation of the main beam: $50 \%$ ). The FAB-matrix was chosen not to interfere with characteristic substance ions. Exact mass measurements were obtained with a FINNIGAN MAT 900S instrument using polyethylene glycol as external standard (accuracy $\pm 5 \mathrm{mu}$ ).

\section{Results and discussion}

\subsection{Free tricyclic antidepressants}

The fast atom bombardment collision-induced (FAB CID MS/MS) mass spectra of the tricyclic antidepressants show characteristic fragmentations: dibenzocycloheptadienes (amitriptyline 1, nortriptyline 2) and dibenzoxepines (doxepine 3, dosulepine 4) produce in the daughter ion mass spectra of their protonated molecular ions similar fragment ions in accordance with their related structures (Table 1). Of importance for screening using the 'constant neutral loss' (CNL) technique are two competing modes, both resulting in a cleavage of the central ring initiated by breaking either of the C-11/C-11a bond (1) or of the C-10/C-11 bond (2) (only for $\mathrm{X}=\mathrm{CH}_{2}$ ) (see Scheme 1). 
Process 1:
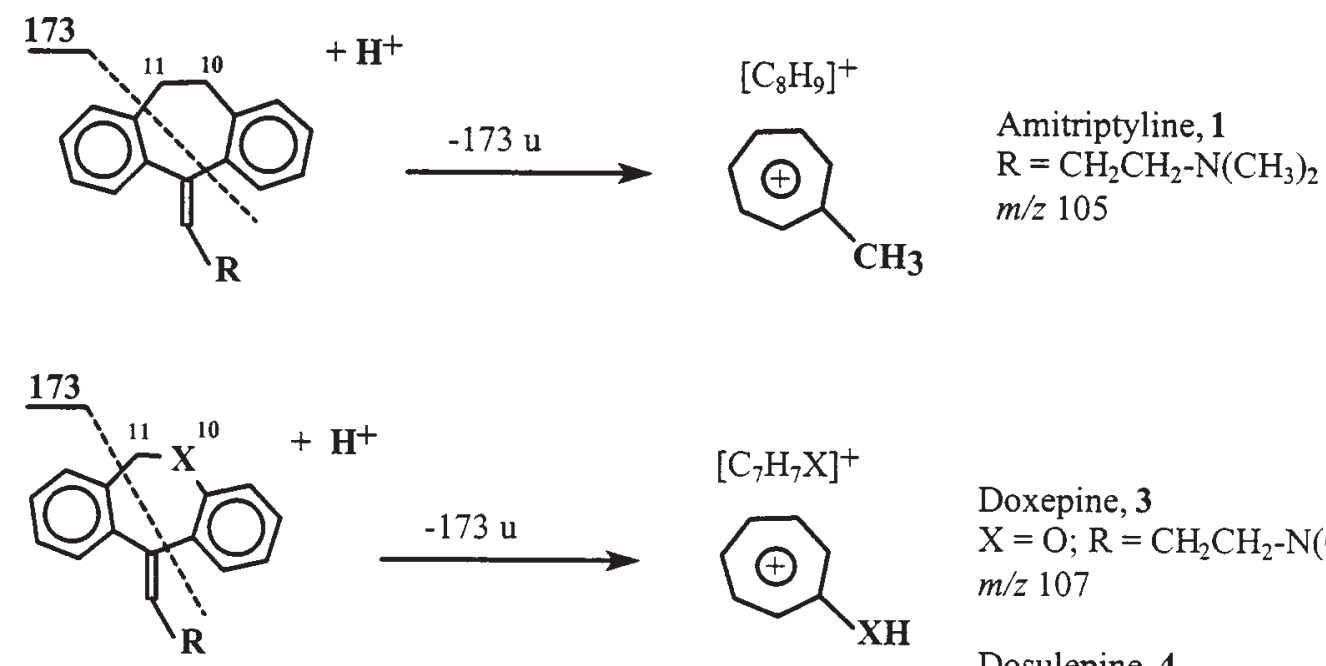
Doxepine, 3
$\mathrm{X}=\mathrm{O} ; \mathrm{R}=\mathrm{CH}_{2} \mathrm{CH}_{2}-\mathrm{N}\left(\mathrm{CH}_{3}\right)_{2}$ $m / z 107$
Dosulepine, 4
$\mathrm{X}=\mathrm{S} ; \mathrm{R}=\mathrm{CH}_{2} \mathrm{CH}_{2}-\mathrm{N}\left(\mathrm{CH}_{3}\right)_{2}$ $m / z 123$

\section{Process 2:}

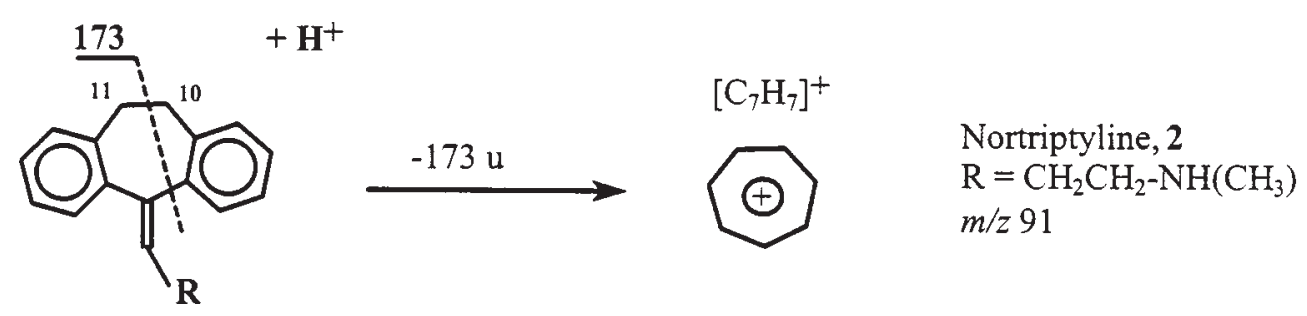

Scheme 1. CID-daughter ions produced by neutral loss of $173 \mathrm{u}$ from $[\mathrm{M}+\mathrm{H}]^{+}$of $\mathbf{1}-\mathbf{4}$.

For the N,N-dimethylamino compounds $\mathbf{1}, \mathbf{3}$ and $\mathbf{4}$ process 1 eliminates $\mathrm{C}-5$ with the side chain and the benzene ring, for the $\mathrm{N}$-methyl compound $\mathbf{2}$ the lower mass of the side chain is compensated by $\mathrm{CH}_{2}$ (C-11, process 2). Consequently, the CNL-scan for $173 \mathrm{u}$ allows the simultaneous detection of the $[\mathrm{M}+\mathrm{H}]^{+}$ions of all four compounds (Scheme 1). Obviously, the $[\mathrm{M}+\mathrm{H}]^{+}$ion of $\mathbf{1}$ loses also $187 \mathrm{u}$ (cleavage 2) and that of $\mathbf{2} 159 \mathrm{u}$ (cleavage 1), but these competing processes are of no importance for the present purpose. A relevant example is given in Fig. 1.

Also the $[\mathrm{M}+\mathrm{H}]^{+}$ions of the dibenzazepine derivatives imipramine 5, desipramine $\mathbf{6}$ and trimipramine 7 fragment under CID conditions in a characteristic way: they lose the entire ring system (195 u) just leaving the side chain (Scheme 2, Table 2). Figure 2 demonstrates the selective detection of these three compounds.

The 10,11-unsaturated opipramol $\mathbf{8}$ under CID conditions behaves in the same way as the saturated dibenzazepines: loss of the ring system (now $193 \mathrm{u}$ ) and formation of the ionized side chain $(\mathrm{m} / \mathrm{z}$ 171) plus the degraded immonium ion $(\mathrm{m} / \mathrm{z}, 143$; Table 3 and Scheme 3$)$. 


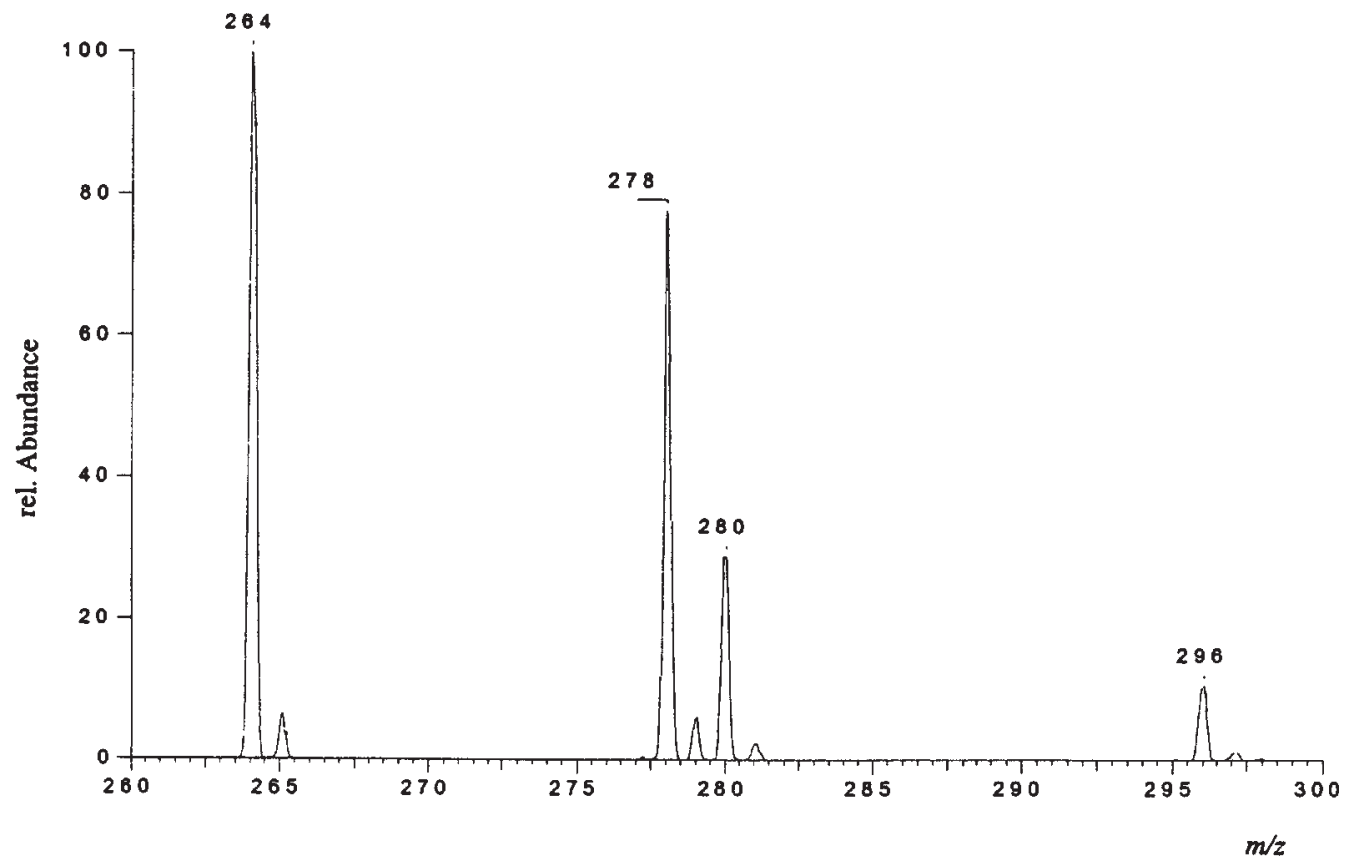

Fig. 1. CNL-scan for $173 \mathrm{u}$ from a mixture of $\mathbf{1 - 4}$.
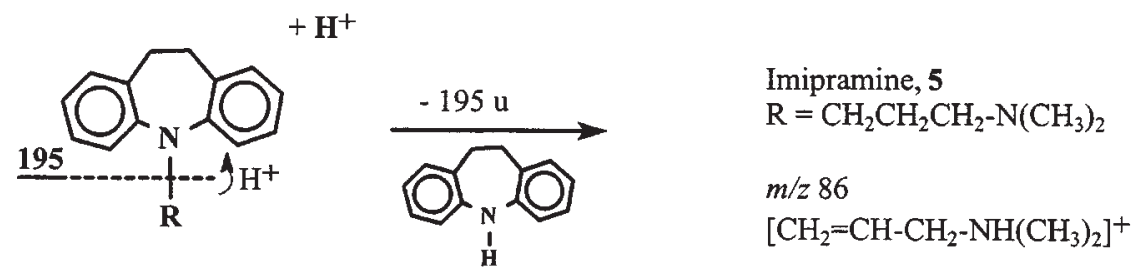

Imipramine, 5

$\mathrm{R}=\mathrm{CH}_{2} \mathrm{CH}_{2} \mathrm{CH}_{2}-\mathrm{N}\left(\mathrm{CH}_{3}\right)_{2}$

$m / z 86$

$\left[\mathrm{CH}_{2}=\mathrm{CH}-\mathrm{CH}_{2}-\mathrm{NH}\left(\mathrm{CH}_{3}\right)_{2}\right]^{+}$

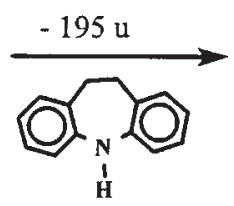

Desipramine, 6

$\mathrm{R}=\mathrm{CH}_{2} \mathrm{CH}_{2} \mathrm{CH}_{2}-\mathrm{NH}\left(\mathrm{CH}_{3}\right)$

$m / 272$

$\left[\mathrm{CH}_{2}=\mathrm{CH}-\mathrm{CH}_{2}-\mathrm{NH}_{2} \mathrm{CH}_{3}\right]^{+}$

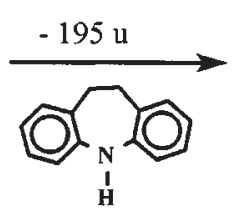

Trimipramine, 7

$\mathrm{R}=\mathrm{CH}_{2}-\mathrm{CH}\left(\mathrm{CH}_{3}\right)-\mathrm{CH}_{2}-\mathrm{N}\left(\mathrm{CH}_{3}\right)_{2}$

$m / z 100$

$\left[\mathrm{CH}_{2}=\mathrm{C}\left(\mathrm{CH}_{3}\right)-\mathrm{CH}_{2}-\mathrm{NH}\left(\mathrm{CH}_{3}\right)_{2}\right]^{+}$

Scheme 2. CID-daughter ions produced by constant neutral loss of $195 \mathrm{u}$ from $[\mathrm{M}+\mathrm{H}]^{+}$of 5-7. 
Table 2

Daughter ion mass spectra and CNL-scans $(195 \mathrm{u})$ from $[\mathrm{M}+\mathrm{H}]^{+}$of 5-7

\begin{tabular}{lllllll}
\hline Compound & $\begin{array}{l}\text { Parent ion } \\
{[\mathrm{M}+\mathrm{H}]^{+}} \\
m / z\end{array}$ & $\begin{array}{l}\text { Daughter ions } \\
\mathrm{m} / z\end{array}$ & $\begin{array}{c}\text { Rel. } \\
\text { Abund. } \\
\%\end{array}$ & $\begin{array}{l}\mathrm{CNL} \\
195 \mathrm{u}\end{array}$ & $\begin{array}{l}\text { Rel. } \\
\text { Abund. } \\
\%\end{array}$ \\
\hline Imipramine 5 & 281 & 86 & {$\left[\mathrm{CH}_{2}=\mathrm{CH}-\mathrm{CH}_{2}-\mathrm{NH}\left(\mathrm{CH}_{3}\right)_{2}\right]^{+}$} & 100 & 281 & 100 \\
& & 58 & {$\left[\mathrm{CH}_{2}=\mathrm{N}\left(\mathrm{CH}_{3}\right)_{2}\right]^{+}$} & 17.5 & & \\
& & $171,155,111$ & 100 & 267 & 100 \\
Desipramine 6 & 267 & 72 & {$\left[\mathrm{CH}_{2}=\mathrm{CH}-\mathrm{CH}_{2}-\mathrm{NH}_{2} \mathrm{CH}_{3}\right]^{+}$} & 100 & \\
Trimipramine 7 & 295 & 100 & {$\left[\mathrm{CH}_{2}=\mathrm{C}\left(\mathrm{CH}_{3}\right)-\mathrm{CH}_{2}-\mathrm{NH}\left(\mathrm{CH}_{3}\right)_{2}\right]^{+}$} & 100 & 295 & 100 \\
& & 58 & {$\left[\mathrm{CH}_{2}=\mathrm{N}\left(\mathrm{CH}_{3}\right)_{2}\right]^{+}$} & 36.9 & & \\
\hline
\end{tabular}

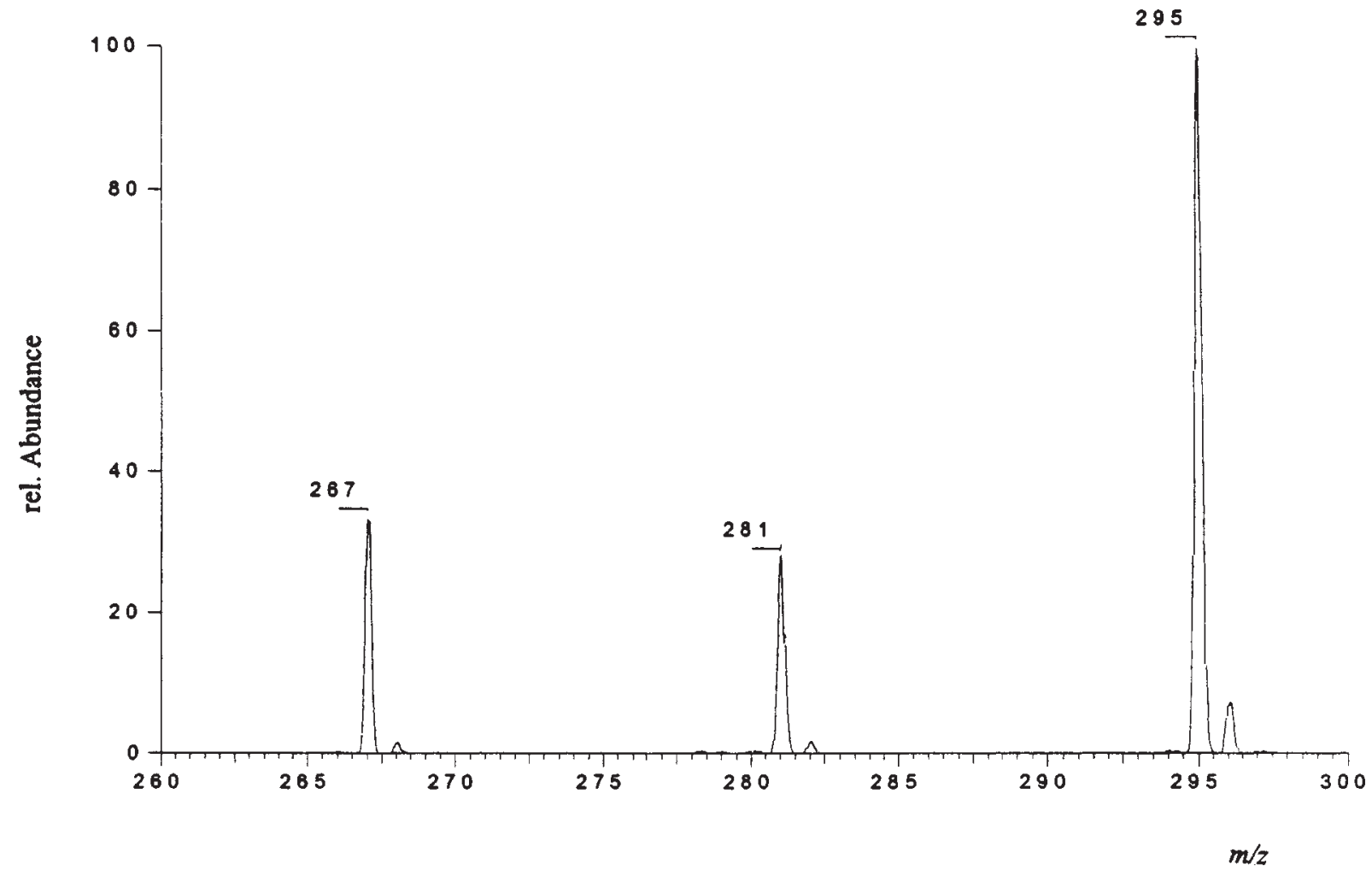

Fig. 2. CNL-scan for 195 u from a mixture of 5-7.

\subsection{Metabolites}

In urine samples in addition to the excreted unaltered drugs their metabolites will be encountered. The urinary metabolites are the products of N-oxidation $(\mathbf{1}, \mathbf{3}, \mathbf{5})$ [9] and $\mathrm{N}$-demethylation of the aliphatic side chain (1-7) [9] and from aliphatic $(\mathbf{1}, \mathbf{2}, \mathbf{5}, \mathbf{6}, \mathbf{7})$ [9] and aromatic hydroxylations (17) $[9,10]$ of the tricyclic skeleton. These biotransformations are completed by N-glucuronidation of aliphatic tertiary amines $(\mathbf{1}, \mathbf{3}, \mathbf{5}, \mathbf{7})[11]$ or O-glucuronidation $(\mathbf{1}, \mathbf{2}, \mathbf{3}, \mathbf{5}, \mathbf{6}, \mathbf{7})[9,10,12]$ of the various hydroxylated metabolites. The $[\mathrm{M}+\mathrm{H}]^{+}$ions of all glucuronides lose upon CID-activation the sugar ring ( $-176 \mathrm{u}$, see Schemes 4 and 5) and may thus be detected by CNL-scans. 
Table 3

Daughter ion mass spectrum and CNL-scan $(193 \mathrm{u})$ from $[\mathrm{M}+\mathrm{H}]^{+}$of 8

\begin{tabular}{llllll}
\hline Compound & $\begin{array}{l}\text { Parent ion } \\
{[\mathrm{M}+\mathrm{H}]^{+}} \\
m / z\end{array}$ & $\begin{array}{l}\text { Daughter ions } \\
m / z\end{array}$ & $\begin{array}{l}\text { Rel. } \\
\text { Abund. }\end{array}$ & $\begin{array}{l}\mathrm{CNL}- \\
193 \mathrm{u} \\
\%\end{array}$ & $\begin{array}{l}\text { Rel. } \\
\text { Abund. } \\
\%\end{array}$ \\
\hline Opipramol 8 & 364 & $171\left[\mathrm{C}_{9} \mathrm{H}_{19} \mathrm{~N}_{2} \mathrm{O}\right]^{+}$ & 100 & 364 & 100 \\
& & $143\left[\mathrm{C}_{7} \mathrm{H}_{15} \mathrm{~N}_{2} \mathrm{O}\right]^{+}$ & 23.8 & & \\
\hline
\end{tabular}

$m / z 364$
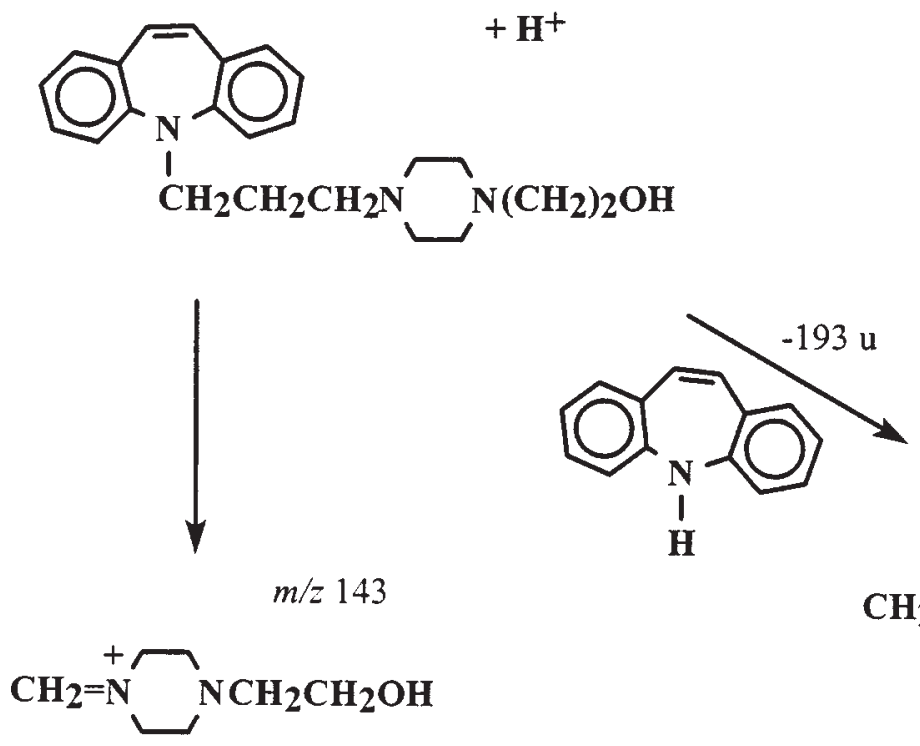

$m / z 171$

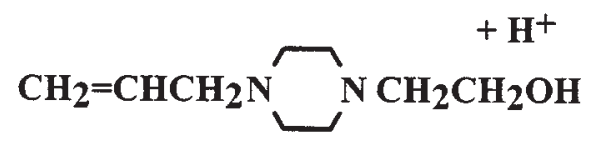

Scheme 3. CID-daughter ions of $[\mathrm{M}+\mathrm{H}]^{+}$from $\mathbf{8}$.

\subsection{Authentic samples}

The results of authentic samples after treatment of patients with different TCA will be presented.

\subsubsection{Sample 1}

A patient (female, 56 years) had obtained a daily dose of $125 \mathrm{mg}$ desipramine. $\mathrm{HCl}(\mathbf{6})$ (Pertofran $\left.{ }^{\circledR}\right)$ ). The protonated molecular ion $[\mathrm{M}+\mathrm{H}]^{+}$at $\mathrm{m} / \mathrm{z} 267$ of $\mathbf{6}$ was detected by the CNL-scan of $195 \mathrm{u}$ (Table 4). This assignment was confirmed by the CID-daughter ion scan (Table 5) which yielded $\mathrm{m} / \mathrm{z}$ 72 (see Scheme 2 and Table 2). In addition, two metabolites of 6 were detected, viz. its hydroxylation product $\left([\mathrm{M}+\mathrm{H}]^{+} \mathrm{m} / \mathrm{z}, 283\right)$ which upon CID also yielded $\mathrm{m} / \mathrm{z}, 72$ characteristic for the side chain (Table 2) and the glucuronide of the latter $\left([\mathrm{M}+\mathrm{H}]^{+} \mathrm{m} / \mathrm{z} 459\right)$. This compound could be detected by a CNL-scan for the loss of $176 \mathrm{u}$ (v. supra) and CID-decomposition resulting in the loss of $176 \mathrm{u}$ $(\mathrm{m} / \mathrm{z} 283$, hydroxylated $\mathbf{6})$ as well as a prominent ion of $\mathrm{m} / \mathrm{z}, 72$.

\subsubsection{Sample 2}

A patient (female, 71 years) had obtained a daily dose of $150 \mathrm{mg}$ amitriptyline. $\mathrm{HCl}(\mathbf{1})$ (Saroten ${ }^{\circledR}$ ). The ion at $\mathrm{m} / \mathrm{z} 278$ was detected with maximum abundance in the CNL-scan for $173 \mathrm{u}$ (Table 4) and could be identified by means of a subsequent CID-daughter ion mass spectrum as the protonated molecular ion $[\mathrm{M}+\mathrm{H}]^{+}$of $\mathbf{1}$ (Table 6; cf. Table 1). In addition, several metabolites of $\mathbf{1}$ were found: 


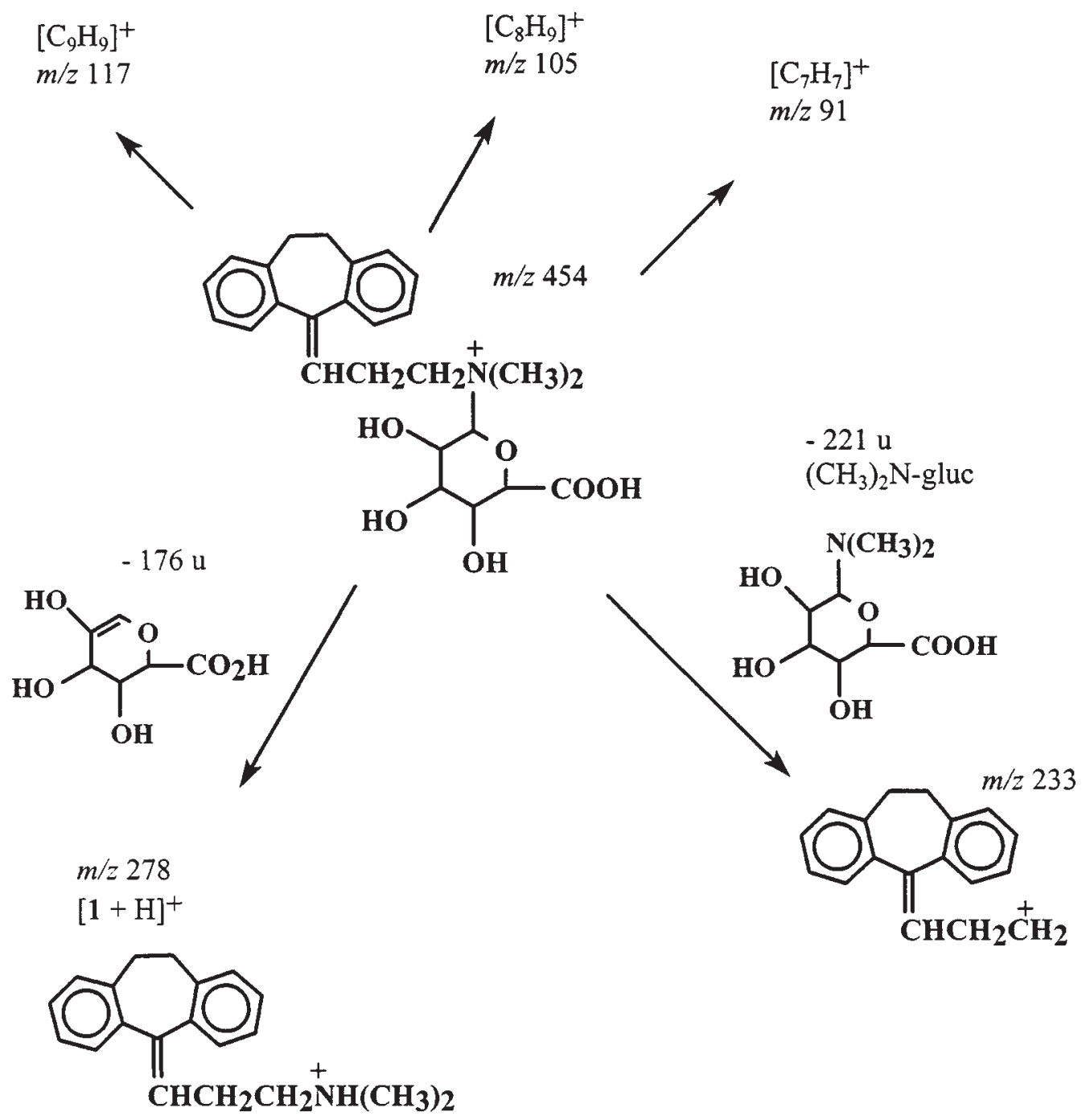

Scheme 4. Fragmentation of the amitriptyline-N-glucuronide $m / z, 454$.

(a) The hydroxylation product of $\mathbf{1}$ with $[\mathrm{M}+\mathrm{H}]^{+}$at $\mathrm{m} / z$ 294. The CID-daughter ion mass spectrum of $\mathrm{m} / \mathrm{z} 294$ shows characteristic fragment ions of amitriptyline viz. $\mathrm{m} / \mathrm{z}$ 91, 105, 117 (Table 6). The ion at $\mathrm{m} / \mathrm{z} 233 \mathrm{can}$ be interpreted by the loss of $\left(\mathrm{CH}_{3}\right)_{2} \mathrm{NOH}(61 \mathrm{u})$ which points towards the formation of 1-N-oxid. On the other hand, the formation of $\left[\mathrm{CH}_{2}=\mathrm{N}\left(\mathrm{CH}_{3}\right)_{2}\right]^{+}(\mathrm{m} / z$ 58) and an ion formed by the loss of $\mathrm{H}_{2} \mathrm{O}$ form $\mathrm{m} / 2294$ suggests a hydroxylation on the $-\mathrm{CH}_{2}-\mathrm{CH}_{2}-(\mathrm{C}-10, \mathrm{C}-11)$ bridge of the ring system. Probably two isomeric metabolites of the same mass are present.

(b) Glucuronides. The CNL-scan for $176 \mathrm{u}$ revealed the presence of three glucuronides with $[\mathrm{M}+\mathrm{H}]^{+}$ $\mathrm{m} / \mathrm{z}$ 454, 456 and 470 (Table 4). The CID-fragments of $\mathrm{m} / \mathrm{z} 454$ (Table 6, Scheme 4) allow an identification by the characteristic fragments of the dibenzocycloheptadiene cyclus at $\mathrm{m} / \mathrm{z} 91,105$ and 117. The appearance of $\mathrm{m} / z 278\left([\mathrm{M}+\mathrm{H}]^{+}\right.$of $\left.\mathbf{1}\right)$ and especially the ion at $\mathrm{m} / z 233$ (loss of the amine function, see Table 1) indicate that $\mathrm{m} / \mathrm{z}, 454$ is the quaternary ammonium-linked glucuronide of $\mathbf{1}$. This was confirmed by a CNL-experiment for $221 \mathrm{u}$ targeting the loss of $\left(\mathrm{CH}_{3}\right)_{2} \mathrm{~N}$-glucuronide 

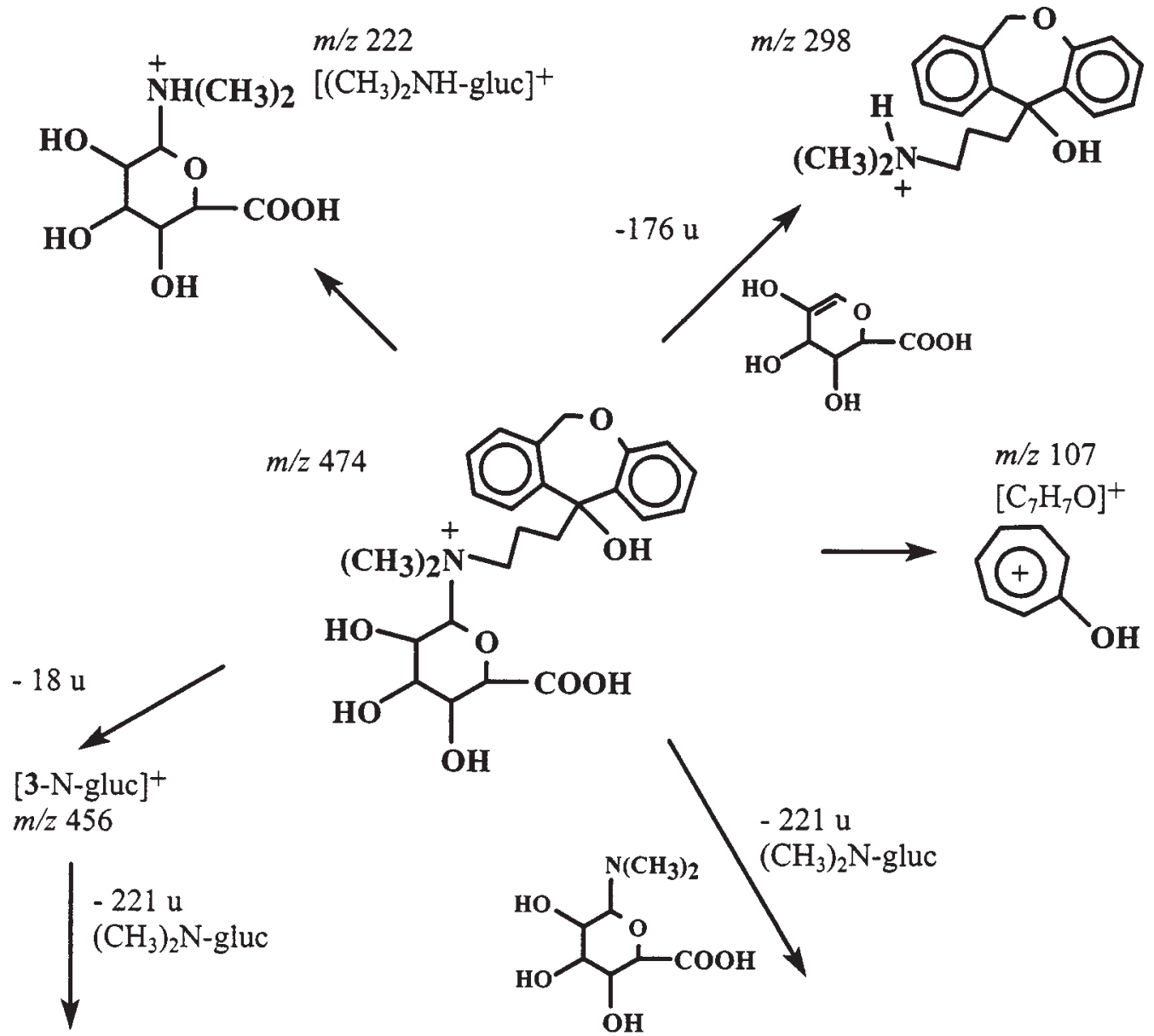

$m / z 253$

$m / z 235$

Scheme 5. Fragmentation of the dihydro hydroxy-doxepine-N-glucuronide $m / z 474$.

yielding an ion at $m / z, 454$ with maximum abundance (cf. Scheme 4).

The second glucuronidated metabolite of 1 shows a $[\mathrm{M}+\mathrm{H}]^{+}$ion at $\mathrm{m} / z$ 456. It is derived from hydroxy-N-nor-1 (= hydroxy-2) as can be deduced from the CID-daughter ion spectrum (Table 6): After loss of $176 \mathrm{u}$ (cf. Scheme 4) $[\mathrm{M}+\mathrm{H}]^{+}(\mathrm{m} / \mathrm{z} 280)$ of the parent compound is obtained. The loss of $194 \mathrm{u}$ (glucuronic acid) leading to $\mathrm{m} / \mathrm{z} 264$ points towards a hydroxylation of the $-\mathrm{CH}_{2}-\mathrm{CH}_{2}-$ bridge (C-10/C-11). The presence of the unaltered monomethylamino side chain is confirmed by the formation of $m / z 70$.

$[\mathrm{M}+\mathrm{H}]^{+}$at $\mathrm{m} / z, 470$ corresponds to the glucuronide of hydroxy-1, probably a mixture of O- and N-derivatives: The loss of 194 u, i.e., of glucuronic acid corresponds to a structure substituted at the $\mathrm{C}-10 / \mathrm{C}-11$ bridge while the formation of an $\mathrm{m} / z 222\left(\left[\left(\mathrm{CH}_{3}\right)_{2} \mathrm{NH} \text {-gluc }\right]^{+}\right)$points towards the formation of a N-glucuronide. 
Table 4

CNL-scans of urine samples $\mathbf{1 - 4}$

\begin{tabular}{|c|c|c|c|c|c|c|c|c|}
\hline Sample & $\begin{array}{l}\text { CNL- } \\
176 \mathrm{u}\end{array}$ & $\begin{array}{l}\text { Rel. } \\
\text { Abund. } \\
\%\end{array}$ & $\begin{array}{l}\text { CNL- } \\
195 \mathrm{u}\end{array}$ & $\begin{array}{l}\text { Rel. } \\
\text { Abund. } \\
\%\end{array}$ & $\begin{array}{l}\text { CNL- } \\
193 \mathrm{u}\end{array}$ & $\begin{array}{l}\text { Rel. } \\
\text { Abund. } \\
\%\end{array}$ & $\begin{array}{l}\text { CNL- } \\
173 \mathrm{u}\end{array}$ & $\begin{array}{l}\text { Rel. } \\
\text { Abund. } \\
\%\end{array}$ \\
\hline 1.6 & $\begin{array}{l}459 \\
445,467, \\
475,497\end{array}$ & $\begin{array}{l}100 \\
\leqslant 30\end{array}$ & $\begin{array}{l}267 \\
264,286, \\
292,295\end{array}$ & $\begin{array}{l}100 \\
\leqslant 30\end{array}$ & - & - & - & - \\
\hline 2. 1 & $\begin{array}{l}454 \\
456 \\
470 \\
453\end{array}$ & $\begin{array}{l}100 \\
39.6 \\
52.9 \\
50\end{array}$ & - & - & - & - & $\begin{array}{l}278 \\
258,260 \\
262,264\end{array}$ & $\begin{array}{l}100 \\
\leqslant 50\end{array}$ \\
\hline 3. 3 & $\begin{array}{l}456 \\
472 \\
474 \\
471,478\end{array}$ & $\begin{array}{l}100 \\
36.3 \\
25.1 \\
\leqslant 20\end{array}$ & - & - & - & - & $\begin{array}{l}280 \\
296 \\
262\end{array}$ & $\begin{array}{l}100 \\
23.4 \\
6\end{array}$ \\
\hline 4. $\mathbf{1}, \mathbf{2}, \mathbf{8}$ & $\begin{array}{l}454 \\
456 \\
470 \\
556 \\
476,486\end{array}$ & $\begin{array}{l}100 \\
13.6 \\
59.4 \\
10 \\
\leqslant 10\end{array}$ & - & - & $\begin{array}{l}364 \\
378\end{array}$ & $\begin{array}{l}42.3 \\
100\end{array}$ & $\begin{array}{l}264 \\
278\end{array}$ & $\begin{array}{l}8.4 \\
100\end{array}$ \\
\hline
\end{tabular}

Table 5

Daughter ion mass spectra from $[\mathrm{M}+\mathrm{H}]^{+}$of sample 1

\begin{tabular}{llll}
\hline $\begin{array}{l}\text { Parent ion } \\
{[\mathrm{M}+\mathrm{H}]^{+}} \\
m / z\end{array}$ & $\begin{array}{l}\text { Daughter ions } \\
m / z\end{array}$ & $\begin{array}{l}\text { Rel. } \\
\text { Abund. } \\
\%\end{array}$ \\
\hline 459 & 283 & {$[\text { hydroxy-6 + H }]^{+}$} & 37.2 \\
& 72 & {$\left[\mathrm{CH}_{2}=\mathrm{CH}-\mathrm{CH}_{2} \mathrm{NH}_{2} \mathrm{CH}_{3}\right]^{+}$} & 100 \\
283 & 72 & {$\left[\mathrm{CH}_{2}=\mathrm{CH}-\mathrm{CH}_{2} \mathrm{NH}_{2} \mathrm{CH}_{3}\right]^{+}$} & 100 \\
& 151,157 & $\leqslant 15$ \\
267 & 72 & {$\left[\mathrm{CH}_{2}=\mathrm{CH}-\mathrm{CH}_{2} \mathrm{NH}_{2} \mathrm{CH}_{3}\right]^{+}$} & 100 \\
& 105 & & 6 \\
\hline
\end{tabular}

\subsubsection{Sample 3}

A patient (female, 55 years) obtained a daily dose of $125 \mathrm{mg}$ doxepine.HCl (3) (Sinquan ${ }^{\circledR}$ ). A CNL-scan for $173 \mathrm{u}$ shows two prominent ions at $\mathrm{m} / \mathrm{z} 280$ and 296 (Table 4). The CID-daughter ion mass spectrum of $\mathrm{m} / \mathrm{z} 280$ produces the characteristic fragment ions of $\mathbf{3}$ (Table 7; cf. Table 1). $\mathrm{m} / \mathrm{z} 296$ stems probably from a mixture of oxidation products of 3 . Regarding the ions $\mathrm{m} / \mathrm{z} 58,84$, 107 and 117 in the daughter ion spectrum, see Table 1 . The ion $\mathrm{m} / \mathrm{z} 123$ can be interpreted as a dihydroxytropylium species (cf. Scheme $1, \mathrm{~m} / \mathrm{z}, 107$ ) suggesting the presence of a hydroxyl-group in the right-hand benzene ring of $\mathbf{3}$. In agreement with a hydroxylation of the benzene ring is the absence of an ion formed by the loss of $\mathrm{H}_{2} \mathrm{O}$ (cf. below $\mathrm{m} / \mathrm{z}$ 296). The formation of $\mathrm{m} / \mathrm{z} 235$ can be explained by a loss of $\left(\mathrm{CH}_{3}\right)_{2} \mathrm{NOH}(61 \mathrm{u})$ which points towards the formation of an $\mathrm{N}$-oxide. Both compounds are typical metabolites of $\mathbf{3}$. The experiment for the detection of glucuronides (CNL-scan for $176 \mathrm{u}$ ) shows abundant ions at $\mathrm{m} / \mathrm{z}, 456,472$ and 474 (Table 4). The ion at $\mathrm{m} / \mathrm{z}, 456$ produces in the CID-daughter ion mass spectrum the protonated molecular ion $[\mathrm{M}+\mathrm{H}]^{+}$of $\mathbf{3}$ at $\mathrm{m} / \mathrm{z} 280$ and its characteristic fragments at $\mathrm{m} / z 107$ and at $\mathrm{m} / z 235$ (Table 7, cf. Table 1). This ion allows the identification of the parent compound as the quaternary ammonium-linked glucuronide of $\mathbf{3}$, because 
Table 6

\begin{tabular}{|c|c|c|c|c|}
\hline \multicolumn{2}{|c|}{$\begin{array}{l}\text { Parent ion } \\
\mathrm{m} / \mathrm{z}\end{array}$} & \multicolumn{2}{|c|}{$\begin{array}{l}\text { Daughter ions } \\
\mathrm{m} / \mathrm{z}\end{array}$} & $\begin{array}{l}\text { Rel. Abund. } \\
\% \\
26.5\end{array}$ \\
\hline$\overline{454}$ & {$[\mathrm{M}]^{+}$} & $\begin{array}{l}278 \\
233 \\
117 \\
105 \\
91 \\
155\end{array}$ & $\begin{array}{l}{[1+\mathrm{H}]^{+}} \\
{\left[454-\left(\mathrm{CH}_{3}\right)_{2} \mathrm{~N} \text {-gluc }\right]^{+}} \\
{\left[\mathrm{C}_{9} \mathrm{H}_{9}\right]^{+}} \\
{\left[\mathrm{C}_{8} \mathrm{H}_{9}\right]^{+}} \\
{\left[\mathrm{C}_{7} \mathrm{H}_{7}\right]^{+}}\end{array}$ & $\begin{array}{l}26.5 \\
100 \\
19.2 \\
11.4 \\
12.7 \\
3\end{array}$ \\
\hline 456 & {$[\mathrm{M}+\mathrm{H}]^{+}$} & $\begin{array}{l}280 \\
262 \\
117 \\
70 \\
235\end{array}$ & $\begin{array}{l}{[\text { hydroxy-2 }+\mathrm{H}]^{+}} \\
{\left[280-\mathrm{H}_{2} \mathrm{O}\right]^{+}} \\
{\left[\mathrm{C}_{9} \mathrm{H}_{9}\right]^{+}} \\
{ }_{1}\left[\mathrm{CH}_{2}=\mathrm{CH}-\mathrm{CH}=\mathrm{NH}_{2}\left(\mathrm{CH}_{3}\right)\right]^{+}\end{array}$ & $\begin{array}{l}31.4 \\
100 \\
3.2 \\
4.9 \\
\leqslant 8\end{array}$ \\
\hline 470 & {$[\mathrm{M}]^{+}$} & $\begin{array}{l}294 \\
276 \\
231 \\
222 \\
58 \\
345\end{array}$ & $\begin{array}{l}{[\text { hydroxy- } 1+\mathrm{H}]^{+}} \\
{[470 \text {-gluc.acid }]^{+}} \\
{\left[276-\mathrm{NH}\left(\mathrm{CH}_{3}\right)_{2}\right]^{+}} \\
{\left[\left(\mathrm{CH}_{3}\right)_{2} \mathrm{NH}-\text { gluc }\right]^{+}} \\
{\left[\mathrm{CH}_{2}=\mathrm{N}\left(\mathrm{CH}_{3}\right)_{2}\right]^{+}}\end{array}$ & $\begin{array}{c}100 \\
70.4 \\
25.7 \\
12.1 \\
32.6 \\
6\end{array}$ \\
\hline 278 & {$[\mathrm{M}+\mathrm{H}]^{+}$} & $\begin{array}{l}233 \\
117 \\
105 \\
91 \\
84 \\
70 \\
58 \\
247\end{array}$ & $\begin{array}{l}{\left[1+\mathrm{H}-\mathrm{NH}\left(\mathrm{CH}_{3}\right)_{2}\right]^{+}} \\
{\left[\mathrm{C}_{9} \mathrm{H}_{9}\right]^{+}} \\
{\left[\mathrm{C}_{8} \mathrm{H}_{9}\right]^{+}} \\
{\left[\mathrm{C}_{7} \mathrm{H}_{7}\right]^{+}} \\
{\left[\mathrm{CH}_{2}=\mathrm{CH}-\mathrm{CH}=\mathrm{N}\left(\mathrm{CH}_{3}\right)_{2}\right]^{+}} \\
{\left[\mathrm{CH}_{2}=\mathrm{CH}-\mathrm{CH}=\mathrm{NH}_{2}\left(\mathrm{CH}_{3}\right)\right]^{+}} \\
{\left[\mathrm{CH}_{2}=\mathrm{N}\left(\mathrm{CH}_{3}\right)_{2}\right]^{+}} \\
7,191,154,130\end{array}$ & $\begin{array}{l}17.1 \\
94.3 \\
100 \\
89.5 \\
60.7 \\
14.0 \\
12.8 \\
\leqslant 10\end{array}$ \\
\hline 294 & {$[\mathrm{M}+\mathrm{H}]^{+}$} & $\begin{array}{l}276 \\
233 \\
117 \\
105 \\
91 \\
58 \\
166,\end{array}$ & $\begin{array}{l}{\left[294-\mathrm{H}_{2} \mathrm{O}\right]^{+}} \\
{\left[294-\left(\mathrm{CH}_{3}\right)_{2} \mathrm{NOH}\right]^{+}} \\
{\left[\mathrm{C}_{9} \mathrm{H}_{9}\right]^{+}} \\
{\left[\mathrm{C}_{8} \mathrm{H}_{9}\right]^{+}} \\
{\left[\mathrm{C}_{7} \mathrm{H}_{7}\right]^{+}} \\
{\left[\mathrm{CH}_{2}=\mathrm{N}\left(\mathrm{CH}_{3}\right)_{2}\right]^{+}} \\
5,74\end{array}$ & $\begin{array}{l}21.7 \\
70.3 \\
88.0 \\
74.2 \\
100 \\
94.8 \\
\leqslant 20\end{array}$ \\
\hline
\end{tabular}

it is formed by the loss of $\left(\mathrm{CH}_{3}\right)_{2} \mathrm{~N}$-gluc $(221 \mathrm{u})$. This assignment is supported by a CNL-scan of $221 \mathrm{u}$. An exact mass measurement confirmed the composition of the ion at $m / z, 456$ as $\mathrm{C}_{25} \mathrm{H}_{30} \mathrm{NO}_{7}$.

The ion at $\mathrm{m} / z 472$ can be interpreted as $[\mathrm{M}+\mathrm{H}]^{+}$of hydroxydoxepine-N-glucuronide because of the characteristic fragments in the CID-daughter ion mass spectrum (Table 7). Regarding the dihydroxytropylium ion $\mathrm{m} / \mathrm{z} 123$, see above; $\mathrm{m} / \mathrm{z} 251$ in turn is formed by the loss of $\left(\mathrm{CH}_{3}\right)_{2} \mathrm{~N}$-gluc $(221 \mathrm{u})$. The composition of $\mathrm{m} / z, 472$ was determined as $\mathrm{C}_{25} \mathrm{H}_{30} \mathrm{NO}_{8}$ by an exact mass measurement.

A CID-daughter ion experiment (Table 7) of the ion $\mathrm{m} / z 474\left(\mathrm{C}_{25} \mathrm{H}_{32} \mathrm{NO}_{8}\right.$ by exact mass measurement) gave fragment ions at $\mathrm{m} / \mathrm{z} 58,107,235$ and 280 corresponding to the doxepine skeleton (cf. Table 1). The ions at $\mathrm{m} / \mathrm{z}, 253$ and at $\mathrm{m} / \mathrm{z} 235$ can be explained by the loss of $221 \mathrm{u}\left(\left(\mathrm{CH}_{3}\right)_{2} \mathrm{~N}\right.$-gluc; see above) from $\mathrm{m} / \mathrm{z} 474$ and $\mathrm{m} / \mathrm{z} 456\left(474-\mathrm{H}_{2} \mathrm{O}\right)$. The low abundance of $\mathrm{m} / \mathrm{z} 474$ as compared with $\mathrm{m} / \mathrm{z} 456$ in the CNL-experiment for $221 \mathrm{u}$ points towards the presence of the hydroxyl group in an aliphatic position. The fragmentation pattern (Scheme 5 and Table 7) is in agreement with 5-hydroxy-dihydro-3-N-glucuronide [10] formed by addition of $\mathrm{H}_{2} \mathrm{O}$ to the exocyclic double bond. 
Table 7

Daughter ion mass spectra of molecular ions $[\mathrm{M}+\mathrm{H}]^{+}$and $[\mathrm{M}]^{+}$of sample 3

\begin{tabular}{|c|c|c|c|c|}
\hline \multicolumn{2}{|c|}{$\begin{array}{l}\text { Parent ion } \\
\mathrm{m} / \mathrm{z}\end{array}$} & \multicolumn{2}{|c|}{$\begin{array}{l}\text { Daughter ions } \\
\mathrm{m} / \mathrm{z}\end{array}$} & $\begin{array}{l}\text { Rel. Abund. } \\
\% \\
44.1\end{array}$ \\
\hline 456 & {$[\mathrm{M}]^{+}$} & $\begin{array}{l}280 \\
235 \\
107 \\
131,\end{array}$ & $\begin{array}{l}{[3+\mathrm{H}]^{+}} \\
{\left[456-\left(\mathrm{CH}_{3}\right)_{2} \mathrm{~N}-\text { gluc }\right]^{+}} \\
{\left[\mathrm{C}_{7} \mathrm{H}_{7} \mathrm{O}\right]^{+}}\end{array}$ & $\begin{array}{l}44.1 \\
100 \\
12.0 \\
\leqslant 5\end{array}$ \\
\hline 472 & {$[\mathrm{M}]^{+}$} & $\begin{array}{l}296 \\
251 \\
123\end{array}$ & $\begin{array}{l}{[\text { hydroxy-3 + H }]^{+}} \\
{\left[472-\left(\mathrm{CH}_{3}\right)_{2} \mathrm{~N} \text {-gluc }\right]^{+}} \\
{\left[\mathrm{C}_{7} \mathrm{H}_{7} \mathrm{O}_{2}\right]^{+}}\end{array}$ & $\begin{array}{l}100 \\
31.9 \\
3.4\end{array}$ \\
\hline 474 & {$[\mathrm{M}]^{+}$} & $\begin{array}{l}456 \\
298 \\
280 \\
253 \\
235 \\
222 \\
107 \\
58 \\
159\end{array}$ & $\begin{array}{l}{\left[474-\mathrm{H}_{2} \mathrm{O}\right]^{+}} \\
{[\text {dihydro hydroxy-3 + H }]^{+}} \\
{[3+\mathrm{H}]^{+}} \\
{\left[474-\left(\mathrm{CH}_{3}\right)_{2} \mathrm{~N} \text {-gluc }\right]^{+}} \\
{\left[456-\left(\mathrm{CH}_{3}\right)_{2} \mathrm{~N} \text {-gluc }\right]^{+}} \\
{\left[\left(\mathrm{CH}_{3}\right)_{2} \mathrm{NH}-\text { gluc }\right]^{+}} \\
{\left[\mathrm{C}_{7} \mathrm{H}_{7} \mathrm{O}\right]^{+}} \\
{\left[\mathrm{CH}_{2}=\mathrm{N}\left(\mathrm{CH}_{3}\right)_{2}\right]^{+}} \\
1,73\end{array}$ & $\begin{array}{l}5 \\
100 \\
5.5 \\
12.5 \\
27.0 \\
40.0 \\
24.0 \\
8.8 \\
\leqslant 10\end{array}$ \\
\hline 280 & {$[\mathrm{M}+\mathrm{H}]^{+}$} & $\begin{array}{l}235 \\
117 \\
107 \\
91 \\
84 \\
58\end{array}$ & $\begin{array}{l}{\left[3+\mathrm{H}-\left(\mathrm{CH}_{3}\right)_{2} \mathrm{NH}\right]^{+}} \\
{\left[\mathrm{C}_{9} \mathrm{H}_{9}\right]^{+}} \\
{\left[\mathrm{C}_{7} \mathrm{H}_{7} \mathrm{O}\right]^{+}} \\
{\left[\mathrm{C}_{7} \mathrm{H}_{7}\right]^{+}} \\
{\left[\mathrm{CH}_{2}=\mathrm{CH}-\mathrm{CH}=\mathrm{N}\left(\mathrm{CH}_{3}\right)_{2}\right]^{+}} \\
{\left[\mathrm{CH}_{2}=\mathrm{N}\left(\mathrm{CH}_{3}\right)_{2}\right]^{+}}\end{array}$ & $\begin{array}{l}11.7 \\
14.1 \\
100 \\
7 \\
31.0 \\
32.9\end{array}$ \\
\hline 296 & {$[\mathrm{M}+\mathrm{H}]^{+}$} & $\begin{array}{l}251 \\
235 \\
123 \\
117 \\
107 \\
84 \\
58 \\
70\end{array}$ & $\begin{array}{l}\left.\text { [hydroxy-3+H- }\left(\mathrm{CH}_{3}\right)_{2} \mathrm{NH}\right]^{+} \\
{\left[296-\left(\mathrm{CH}_{3}\right)_{2} \mathrm{NOH}\right]^{+}} \\
{\left[\mathrm{C}_{7} \mathrm{H}_{7} \mathrm{O}_{2}\right]^{+}} \\
{\left[\mathrm{C}_{9} \mathrm{H}_{9}\right]^{+}} \\
{\left[\mathrm{C}_{7} \mathrm{H}_{7} \mathrm{O}\right]^{+}} \\
{\left[\mathrm{CH}_{2}=\mathrm{CH}-\mathrm{CH}=\mathrm{N}\left(\mathrm{CH}_{3}\right)_{2}\right]^{+}} \\
{\left[\mathrm{CH}_{2}=\mathrm{N}\left(\mathrm{CH}_{3}\right)_{2}\right]^{+}}\end{array}$ & $\begin{array}{l}12.1 \\
45.0 \\
100 \\
21.3 \\
84.5 \\
84.9 \\
66.6 \\
24\end{array}$ \\
\hline
\end{tabular}

\subsubsection{Sample 4}

This sample stems from a fatal case after a TCA-overdose (female, 50 years). The plasma levels were $0.31 \mathrm{mg} / \mathrm{l} \mathbf{1}, 0.39 \mathrm{mg} / \mathrm{l} \mathbf{2}$ and $0.29 \mathrm{mg} / \mathrm{l} \mathbf{8}$. As a mixture of TCA's had been taken the components had to be identified by their respective characteristic CNL-scans. The CNL-scan of $173 \mathrm{amu}$ shows two abundant ions at $\mathrm{m} / \mathrm{z} 278$ and 264. Subsequent CID-daughter ion mass spectra of the two $[\mathrm{M}+\mathrm{H}]^{+}$ ions (Table 8) and comparison with the reference data (Table 1) allow the identification as $\mathbf{1}$ and $\mathbf{2}$. In the CNL-scan for $193 \mathrm{u}$ the ions at $\mathrm{m} / z 364$ and $\mathrm{m} / \mathrm{z} 378$ are of prominent abundance. The CIDdaughter ion mass spectrum of $\mathrm{m} / \mathrm{z} 364$ shows the two characteristic fragment ions of 8 at $\mathrm{m} / \mathrm{z} 171$ and 143.

The CID-fragments of the ion at $\mathrm{m} / \mathrm{z} 378$ correspond to those of 8 but shifted by $14 \mathrm{u}$. The increase in mass, therefore, must have occurred in the side chain $(\mathrm{m} / \mathrm{z} 171 \rightarrow 185)$ and more specifically in the part without the $-\mathrm{CH}_{2} \mathrm{CH}_{2}-$ group attached to the iminostilbene nucleus $(\mathrm{m} / \mathrm{z} 143 \rightarrow 157)$. According to an exact mass measurement $\mathrm{m} / z, 378$ has the composition $\mathrm{C}_{23} \mathrm{H}_{28} \mathrm{~N}_{3} \mathrm{O}_{2}$, the mass increase comes, therefore, from $+\mathrm{O}-2 \mathrm{H}$. Reports on the metabolism of $\mathbf{8}$ are rather limited [13] but the oxidation of the piperazine ring to give a lactam function (e.g., $\mathbf{a} \rightarrow \mathbf{b}$, Scheme 6) is a known metabolic process [14] 
Table 8

Daughter ion mass spectra from $[\mathrm{M}+\mathrm{H}]^{+}$and $[\mathrm{M}]^{+}$of sample 4

\begin{tabular}{|c|c|c|c|}
\hline $\begin{array}{l}\text { Pare } \\
m / z\end{array}$ & ion & $\begin{array}{l}\text { Daughter ions } \\
\mathrm{m} / \mathrm{z}\end{array}$ & $\begin{array}{l}\text { Rel. Abund. } \\
\%\end{array}$ \\
\hline 556 & {$[\mathrm{M}+\mathrm{H}]^{+}$} & $\begin{array}{ll}538 & {\left[556-\mathrm{H}_{2} \mathrm{O}\right]^{+}} \\
380 & \text { hydroxy-8 + H }^{+} \\
171 & {\left[\mathrm{C}_{9} \mathrm{H}_{19} \mathrm{~N}_{2} \mathrm{O}\right]^{+}} \\
143 & {\left[\mathrm{C}_{7} \mathrm{H}_{15} \mathrm{~N}_{2} \mathrm{O}\right]^{+}}\end{array}$ & $\begin{array}{l}10.5 \\
6.7 \\
100 \\
4.6\end{array}$ \\
\hline 380 & {$[\mathrm{M}+\mathrm{H}]^{+}$} & $\begin{array}{l}171 \quad\left[\mathrm{C}_{9} \mathrm{H}_{19} \mathrm{~N}_{2} \mathrm{O}\right]^{+} \\
143 \quad\left[\mathrm{C}_{7} \mathrm{H}_{15} \mathrm{~N}_{2} \mathrm{O}\right]^{+} \\
319,\end{array}$ & $\begin{array}{l}100 \\
12.7 \\
\leqslant 4\end{array}$ \\
\hline 378 & {$[\mathrm{M}+\mathrm{H}]^{+}$} & $\begin{array}{l}185 \\
157 \\
98\end{array}$ & $\begin{array}{l}100 \\
15.7 \\
4\end{array}$ \\
\hline 364 & {$[\mathrm{M}+\mathrm{H}]^{+}$} & $\begin{array}{ll}171 & {\left[\mathrm{C}_{9} \mathrm{H}_{19} \mathrm{~N}_{2} \mathrm{O}\right]^{+}} \\
143 & {\left[\mathrm{C}_{7} \mathrm{H}_{15} \mathrm{~N}_{2} \mathrm{O}\right]^{+}} \\
85 & \end{array}$ & $\begin{array}{l}100 \\
24.6 \\
2\end{array}$ \\
\hline 470 & {$[\mathrm{M}]^{+}$} & $\begin{array}{ll}294 & \text { [hydroxy-1 + H }^{+} \\
276 & \left.{ }^{+} \text {470-gluc.acid }\right]^{+} \\
58 & {\left[\mathrm{CH}_{2}=\mathrm{N}\left(\mathrm{CH}_{3}\right)_{2}\right]^{+}}\end{array}$ & $\begin{array}{l}100 \\
82.9 \\
12.1\end{array}$ \\
\hline 456 & {$[\mathrm{M}+\mathrm{H}]^{+}$} & $\begin{array}{ll}280 & {[\text { hydroxy-2 + H }]^{+}} \\
262 & {[456 \text {-gluc.acid }]^{+} /\left[280-\mathrm{H}_{2} \mathrm{O}\right]^{+}}\end{array}$ & $\begin{array}{l}71.0 \\
100\end{array}$ \\
\hline 454 & {$[\mathrm{M}]^{+}$} & $278,233,117,105,91$ see Table 6 & \\
\hline 294 & {$[\mathrm{M}+\mathrm{H}]^{+}$} & $276,233,117,105,91,84,58$ see Table 6 & \\
\hline 280 & {$[\mathrm{M}+\mathrm{H}]^{+}$} & $\begin{array}{ll}262 & {\left.\text { hhydroxy-2 }+\mathrm{H}-\mathrm{H}_{2} \mathrm{O}\right]^{+}}_{105}\left[\mathrm{C}_{8} \mathrm{H}_{9}\right]^{+} \\
70 & {\left[\mathrm{CH}_{2}=\mathrm{CH}-\mathrm{CH}=\mathrm{NH}_{2}\left(\mathrm{CH}_{3}\right)\right]^{+}} \\
58 & {\left[\mathrm{CH}_{2}=\mathrm{CH}-\mathrm{NH}_{2}\left(\mathrm{CH}_{3}\right)\right]^{+}} \\
84 & \\
231, & \\
& \end{array}$ & $\begin{array}{l}76.0 \\
100 \\
28.5 \\
18.0 \\
19.8 \\
\leqslant 12\end{array}$ \\
\hline 278 & {$[\mathrm{M}+\mathrm{H}]^{+}$} & $233,117,105,91,84,58$ see Table 1 & \\
\hline 264 & {$[\mathrm{M}+\mathrm{H}]^{+}$} & $233,117,105,91,70$ see Table 1 & \\
\hline
\end{tabular}

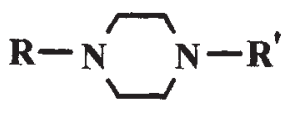

a

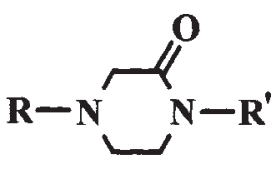

b

Scheme 6.

which explains the mass increase.

The $176 \mathrm{u}$-CNL-scan for glucuronide conjugates shows prominent ions at $\mathrm{m} / \mathrm{z} 454,456,470$ and 556 (Table 4). The glucuronides of $\mathbf{1}(\mathrm{m} / \mathrm{z} 454)$, of hydroxy-1 $(\mathrm{m} / \mathrm{z} 470)$ and of hydroxy-2 $(\mathrm{m} / \mathrm{z} 456)$ can be identified by their characteristic fragments in their CID-daughter ion mass spectra (Table 8 and discussion of Sample 2).

The glucuronide ion at $\mathrm{m} / z 556$ yields upon CID the fragments $\mathrm{m} / \mathrm{z} .171$ and 143 characteristic for 
the side chain of $\mathbf{8}$ as well as $\mathrm{m} / z 380\left([\mathrm{M}+\mathrm{H}]^{+}\right.$of hydroxy-8). CID of $\mathrm{m} / z 380$ (the composition of hydroxy- 8 was determined by high resolution mass measurement as: $\mathrm{C}_{23} \mathrm{H}_{30} \mathrm{~N}_{3} \mathrm{O}_{2}$ ) as expected gives also rise to the ions $\mathrm{m} / \mathrm{z}, 171$ and 143. It follows that the O-glucuronide of hydroxy-8 was formed.

\section{Conclusion}

Urine samples from persons under TCA medication were purified only by adsorption on XADcolumns and elution with $\mathrm{CH}_{3} \mathrm{OH}$ and were subsequently subjected to FAB mass spectrometry. CNLscans allowed to recognize the various structure types excreted in unaltered as well as in metabolized form. CID-mass spectra of the various molecular ions confirmed the conclusions drawn from the molecular masses (oxidation, hydroxylation, addition of $\mathrm{H}_{2} \mathrm{O}$, demethylation and conjugation with glucuronic acid) and gave structural information (hydroxylation in the aromatic or aliphatic part, formation of an $\mathrm{O}$ - or $\mathrm{N}$-glucuronide). The sensitivity of the method is sufficient to detect therapeutic doses (limit $<1 \mu \mathrm{g} / \mathrm{ml}$ urine). Our experiments were performed with a research instrument. The sensitivity of the method may be increased with a triple-quad mass spectrometer which has a much higher transmission than the HSQ-30 with a magnetic and an electrostatic analyzer.

\section{References}

[1] M. Adamczyk, J.R. Fishpaugh and C. Harrington, Ther. Drug Monit. 17 (1995), 371.

[2] A. Tracqui, P. Kintz, S. Ritter-Lohner, P. Mangin, A. Lugnier and A. Chaumont, Hum. Exp. Toxicol. 9 (1990), 257.

[3] G.M. Meenan, S. Barlotta and M. Lehrer, J. Anal. Toxicol. 14 (1990), 273.

[4] H. Maurer and K. Pfleger, J. Chromatogr. 305 (1984), 309.

[5] K.M. Straub, in: Mass Spectrometry in Biomedical Research, S.J. Gaskell, ed., John Wiley \& Sons Ltd., Chichester, 1986, p. 115.

[6] A. Prox and U. Breyer-Pfaff, Drug Metab. Dispos. 15 (1987), 890.

[7] H. Brzezinka, P. Bold and H. Budzikiewicz, Biol. Mass Spectrom. 22 (1993), 346.

[8] K.M. Straub, P. Rudewicz and C. Garvie, Xenobiotica 17 (1987), 413.

[9] M.H. Bickel, in: Handbook of Experimental Pharmacology Series, F. Hoffmeister and G. Stille, eds, Vol. 55/I, Springer, Berlin, 1980, p. 551.

[10] Y.-Z. Shu, J.W. Hubbard, J.K. Cooper, G. McKay, E.D. Korchinski, R. Kumar and K.K. Midha, Drug Metab. Dispos. 18 (1990), 735.

[11] H. Luo, E.H. Hawes, G. McKay, E.D. Korchinski and K.K. Midha, Xenobiotica 25 (1995), 291.

[12] B. Baier-Weber, A. Prox, H. Wachsmuth and U. Breyer-Pfaff, Drug Metab. Dispos. 16 (1988), 490.

[13] G. Skopp, E. Miltner and R. Aderjan, Forensic Sci. Int. 77 (1996), 45.

[14] U. Breyer-Pfaff, in: Handbook of Experimental Pharmacology Series, F. Hoffmeister and G. Stille, eds, Vol. 55/I, Springer, Berlin, 1980, p. 287. 


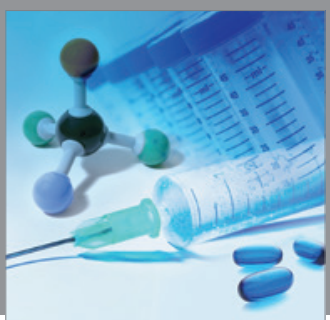

International Journal of

Medicinal Chemistry

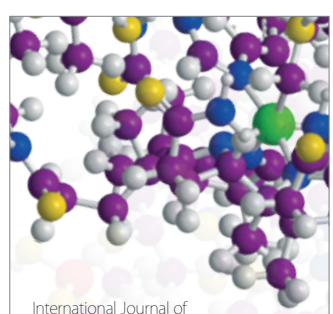

Carbohydrate Chemistry

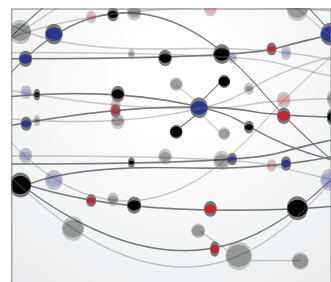

The Scientific World Journal
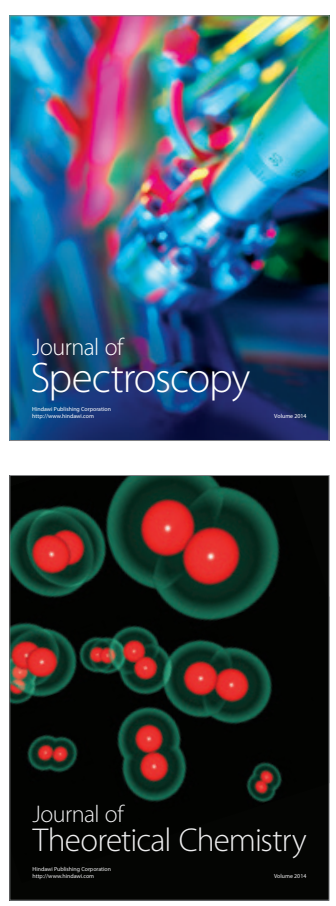
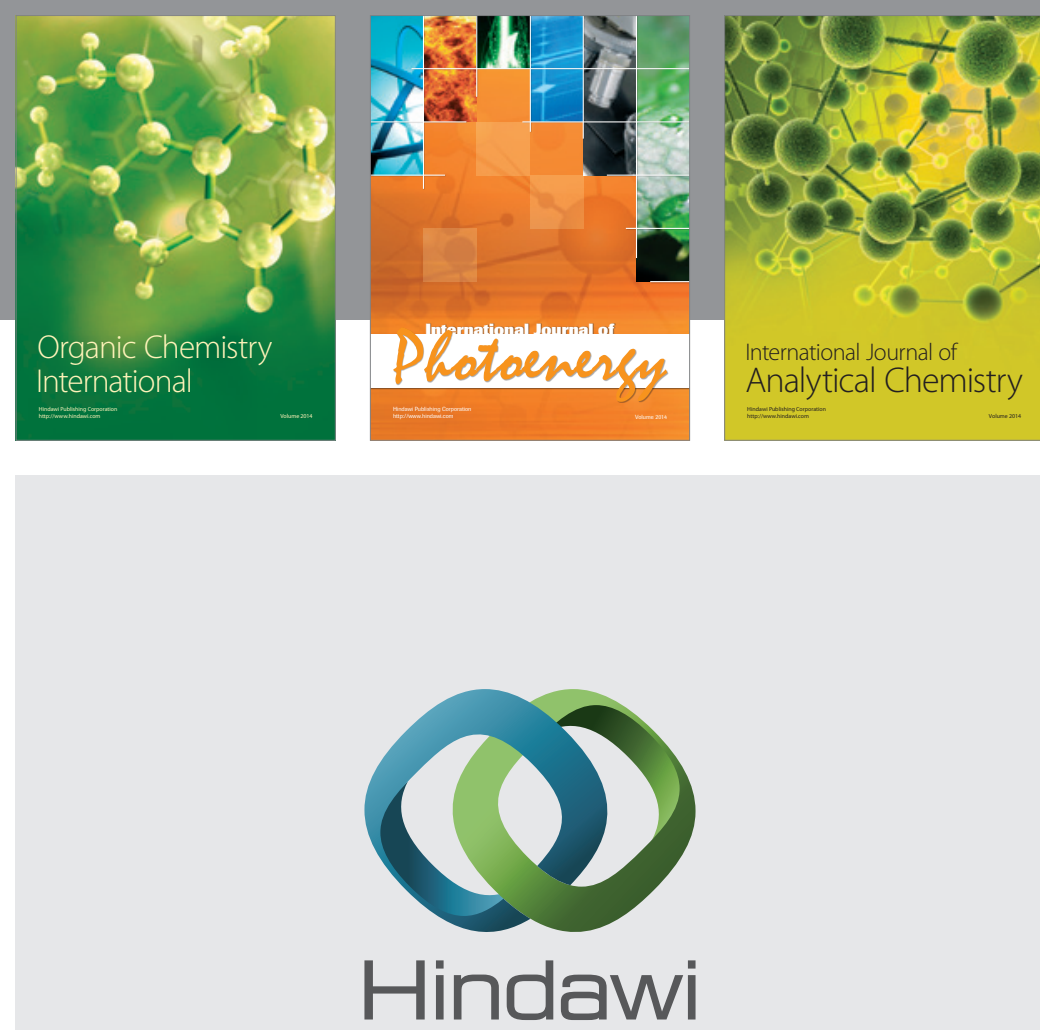

Submit your manuscripts at

http://www.hindawi.com
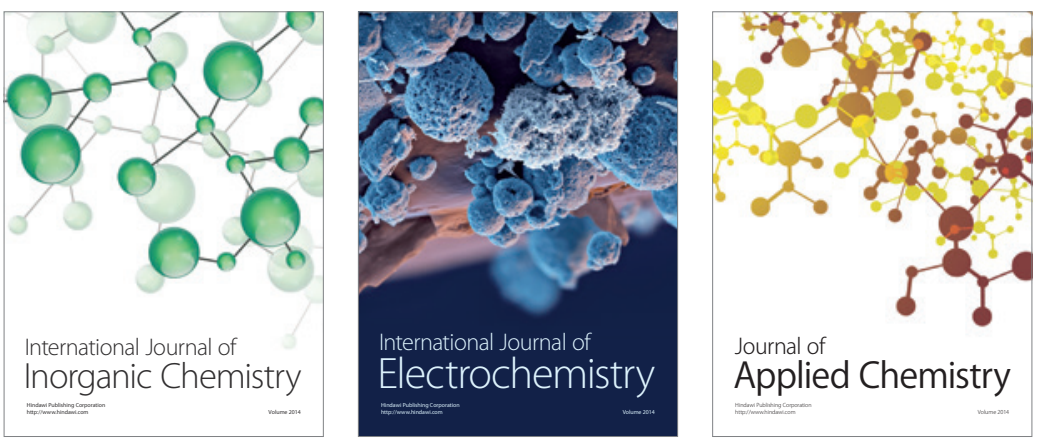

Journal of

Applied Chemistry
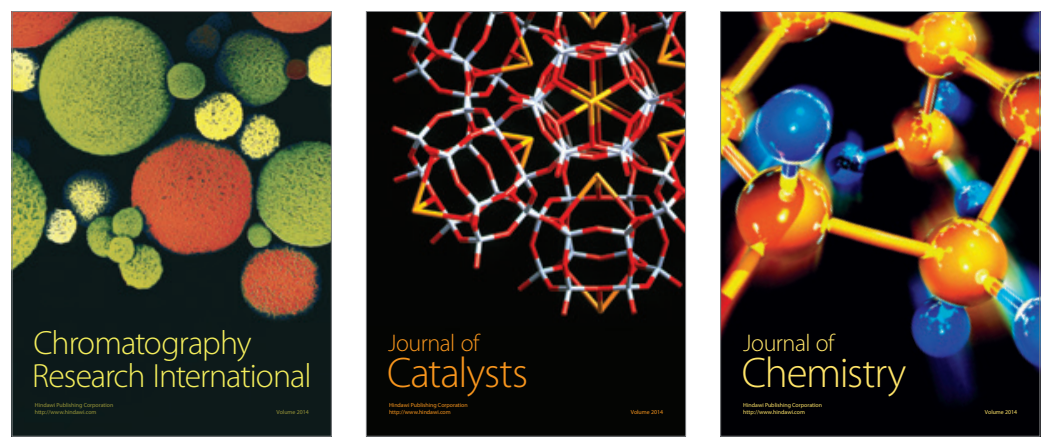
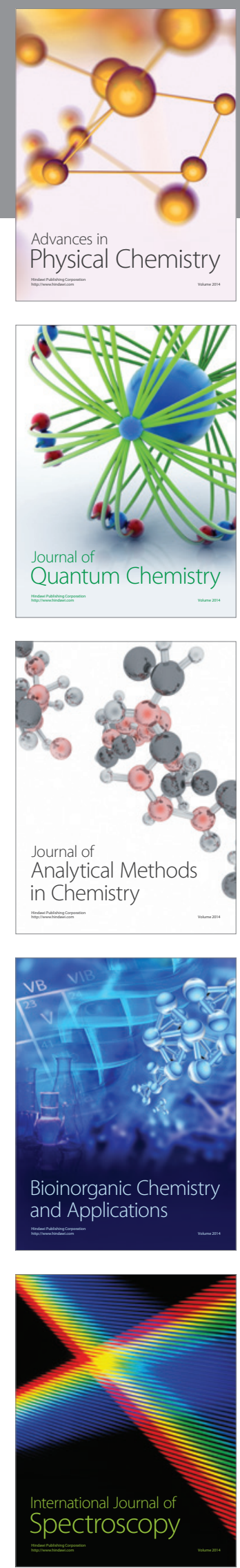